\title{
RESPONSE OF SOYBEAN PLANTS TO INOCULATION WITH RHIZOBIA AND CYANOBACTERIA
}

\author{
M. A. El-Howeity ${ }^{(1)^{\star}}$ and Sh. A. Abdel-Gawad ${ }^{(2)}$ \\ (1) Environmental Studies\& Research Institute (ESRI), Sadat City University, Egypt. \\ (2) Soils, Water and Environ. Res. Institute, Agric. Res., Center, Giza, Egypt. \\ *Corresponding author: E.mail: Mohamed elhoweity@esri.use.edu.eg, elhweity @yahoo.com
}

Received: Jan. 30,2017

Accepted: Mar. 6, 2017

\begin{abstract}
Field experiments were carried out on a clayey alluvial soil to evaluate the effect of (Bradyrhizobium japonicum (B.j), ,Nostoc muscorum, Anabaena oryzae, B.j. +Nostc, B.j.+Anabaena, and B.j.+Nostc+Anabaena, on soybean (Glycine max L.) vegetative growth, root nodulation status, yield and its components. Also, microbial activity in soybean rhizosphere soil and technology characters of seeds (protein, oil, and carbohydrate content) were determined. Results indicated that, inoculation with Brady rhizobium or cyanobacteria improved plant growth parameters, i.e., plant height, number of branches, number and dry weight of pods above the control $(60 \mathrm{kgN})$. However, co-inoculation of Brady rhizobium with the two cyanobacteria significantly enhanced those parameters, where they scored significant increases in number and dry weight of root nodules, as well as nitrogenase activity of the root system, as compared with the single inoculation with Brady rhizobium alone or the control. The mixed inoculation improved dehydrogenase activity in the rhizosphere soil, as well as the seed content of oil, protein and carbohydrate were achieved. Also, the highest yield and its components were also recorded with the mixed inoculation.
\end{abstract}

Key words: Glycine max, $N_{2}$-Fixation, Brady rhizobium Nostoc, Anabaena, plant growth parameters.

\section{INTRODUCTION}

Soybean (Glycine max) is one of the most important oil seeds in the world. It contains $18-22 \%$ oil, $40-45 \%$ protein, $30 \%$ carbohydrate and total sugar about $10 \%$. Moreover, it is also a good source of calcium, phosphorus, copper, potassium, magnesium and thiamine. It is used in food industry for flour, oil, cookies, candy, milk, vegetable chees, lecithin and many other products, (Masuda and Goldsmith, 2009). However, soybean oil can be converted to biodiesel and glycerol. Soybean production in Egypt has increased, since it started in 1976 , and its yield had reached to about 966 ha. about 2895 metric ton per hectare (EI Agroudy et al., 2011). Mineral fertilizers are essential components of modern Agriculture. Intensive crop cultivation requires the use of nitrogen fertilizers. However, fertilizers are short supply, expensive and environmentally hazardous. Therefore, it is important to explore the possibility of supplementing nitrogen in the form of biofertilizers derived from microbial origin. .Biofertilizers are safe environmentally, cheaper and at the same time satisfy the nutrient demands of crop plants (Badawy et al., 1996).

Ecological interactions between rhizobia and other soil bacteria have been of interest in recent years because of their agronomical implications. Many papers have reported enhancement of nodulation and growth and yield of legumes, Hungria and Nogueira (2013) found that, co-inoculation with rhizobia and Azospirillum increased the yield of soybean by $16-19 \%$ above control. Also, Kumar et al. (2016) found that, inoculation of Phaseolus valgaris with mixed inocula was more effective, compared with single inoculation and increased plant height, nodulation, number of pods per plant, seed per pod and grain yield in pot and field 
experiments. Likewise, Elsayed et al. (2016) observed that, using non-invasive spectral detection, coinoculation of peanut with Bradyrhizobium and PGPR increased yield of two cultivars, compared to single inoculation.

In recent years, more worldwide and more attention has been paid to use cyanobacteria that occur in almost every environment on the earth and several species are known to form symbiotic associations with bacteria, as well as with eukaryote (Bergman et al. 2007). Many cyanobacteria are capable of $\mathrm{N}_{2}$ fixation and taking up and assimilating organic compounds, which may play an important role in secondary metabolism (Prasanna et al.2004). Moreover, some cyanobacteria may produce plant growth -promoting substances and play an important role in building up soil fertility (Sergeeva et al. 2002).

Cyanobacteria strains belonging to the genera Nostoc and/or Anabaena can be used as alternative to increase soil productivity and improve plant growth in a sustainable agriculture regime. There is currently great interest in developing new associations with many plants. Aref and AlKassas (2006) study the effect of cyanobacterial inoculation as a nitrogen source may substitute partially on maize plants. They found that, using cyanobacteria significantly increased maize yield above the control.

The aim of this work was to investigate the effect of single and dual inoculation with cyanobacteria and rhizobia on growth, nodulation status, crop yield, yield components and microbial activity in rhizosphere soil of soybean cultivated inalluvial clay soil.

\section{MATERIALS AND METHODS}

Two field experiments were carried out in a private farm at Ashmon, Meinufiya Governorate, Egypt, during two successive summer seasons, i.e. 2012/2013 and 2013/2014 to study the effect of inoculation with cyanobacteria alone or coinoculation with rhizobia. Treatments carried out were: control $(60 \mathrm{kgN} / \mathrm{fed}$.$) , Nostoc muscorum,$ Anabaena oryzae, Bradyrhizobium japonicum (B.j.), (B.j.), +Nostc, (B.j.)+ Anabaena, and (B.j.)+ Nostc+ Anabaena each with $30 \mathrm{~kg} \mathrm{~N} / \mathrm{fed}$, on soybean vegetative growth, nodulation status, nitrogenase activity, yield and yield components, as well as dehydrogenase activity in the rhizosphere soil of plants. Biochemical constituents of seeds (protein, oil, and carbohydrates) were also determined. The soil of the experimental field plots was clayey in texture, having $\mathrm{pH}$ 7.70 , organic matter $2.2 \%$, total N $0.21 \%$, available P $0.03 \%$, according to Page et al. (1982). The field was prepared by ploughing and puddling, then divided into 21plots $(3 \mathrm{~m} \times 3 \mathrm{~m}), 7$ treatments each with three replicates, in a randomized block design. Soybean seeds variety "Giza 111", were inoculated with cyanobacteria inoculum, Nostoc muscorum, Anabaena oryzae and Brady rhizobium sp. either of individually or mixed. All strains were kindly supplied by the Microbial. Dept., Soils, Water \& Environ Res. Inst. Agric. Res. Center (ARC), Giza, Egypt.

\section{Analytical procedures: \\ - Plant growth criteria:}

Plant height, number of branches, shoot dry weight, number of pods and pod dry weight, were determined after 75 days of planting, as well as number of root nodules, dry weight of nodules, nitrogenase and rhizosphere dehydrogenase activity, were also determined.

\section{Contents of seed constituents:}

- Oil was determined by Soxhlet extraction as described by A.O.A.C.(1990).

- Protein was determined as nitrogen by micro Kjeldal method, according to A.O.A.C. (1990), then calculated by multiplying $\mathrm{N} \%$ in the factor 6.25 to get the protein content. 
- Carbohydrate was determined by phenolsulfuric acid, according to Dubois et al . (1956).

- Dehydrogenase activity : colourimetrically, for the 2,3,5- triphenyl formazan (TPF) produced from the reduction of $2,3,5$ triphenyl tetrazolium chloride (TTC), using acetone for extraction (Thalmann.,1967).

- Nitrogenase: by means of gas liquid chromatograph for ethylene produced from the reduction of acetylene (Hardy et al., 1973).

At maturity, a sample of five guarded plants were uprooted to measure number of branches ,number of pods, number of seeds /pod, seed index ( 100 seed weight) and seed yield/plant, then the four inner rows were harvested to calculate seed yield /fed. Analyses of variance were computed, according to Gomez and Gomez (1984) using the least significant difference at 0.05 level to compare the differences among means.

\section{RESULTS AND DISCUSSION Effect of microbial inoculation on growth of soybean plants}

Data in Table (1) indicate that, cyanobacterial inoculation and rhizobia, either individually or mixed improved the vegetative parameters measured.

Results showed that the mixed microbial inoculation showed the highest records of almost all parameters under study, compared to the other treatment. The treatment with (B.j.) +Nostc+Anabaena +30 $\mathrm{kg} \mathrm{N} / \mathrm{fed}$, was mostly the best significantly. Shoots dry weight increased with $15 \%$ by using the mixture of inocula, as compared with other treatments.

The addition of cyanobacteria singlely plus half dose of mineral fertilizer could not compensate the full dose, of nitrogen fertilizer. Previous results obtained ( Sekina Tantawy and Nagwa atef, 2010) who found that, coinoculation with cyanobacteria plus Azospirillum or Azotobacter provoked germination and increased growth parameters in Lupinus termis. Earlier reports had shown that, inoculation with rhizobia stimulated the growth of plants by providing not only fixed $\mathrm{N}$ but also by increasing microbial diversity and structure in the plant rhizosphere (Trabelsi et al., 2012). Likewise, coinoculation including cyanobacteria scored the heights figures, being due to the contribution of cyanobacteria not only in $\mathrm{N}_{2}$ fixation, but also in increasing organic matter content in soil. Karthikeyan et al. (2007) reported that, cyanobacteria excrete IAA, amino acids and other growthpromoting compounds into their immediate environment and stimulate microbial population in the rhizosphere soil .

Table (1): Effect of cyanobacteria and rhizobial inoculation on growth parameters of soybean plants.

\begin{tabular}{|l|c|c|c|c|c|c|c|c|c|}
\hline \multirow{2}{*}{ Treatments } & \multicolumn{3}{|c|}{ Plant Height (Cm) } & \multicolumn{3}{c|}{$\begin{array}{c}\text { Shoot dry weight } \\
\text { (g/plant) }\end{array}$} & \multicolumn{3}{c|}{ Number of branches } \\
\cline { 2 - 11 } & $\mathrm{S} 1$ & $\mathrm{~S} 2$ & Mean & S1 & S2 & Mean & S1 & S2 & Mean \\
\hline Control $(60 \mathrm{kgN})$ & 78.70 & 76.25 & $77.47 \mathrm{~b}$ & 27.44 & 29.40 & $28.42 \mathrm{c}$ & 1.67 & 2.00 & $1.83 \mathrm{dc}$ \\
\hline Nostoc+30kgN & 70.21 & 67.25 & $68.94 \mathrm{~d}$ & 24.30 & 25.11 & $24.70 \mathrm{e}$ & 1.00 & 1.33 & $1.66 \mathrm{e}$ \\
\hline Anabaena+30kgN & 63.94 & 67.88 & $65.91 \mathrm{e}$ & 24.13 & 24.42 & $24.28 \mathrm{e}$ & 1.00 & 1.67 & $1.33 \mathrm{de}$ \\
\hline B. japonicum +30kgN & 74.74 & 73.74 & $47.24 \mathrm{c}$ & 26.41 & 27.91 & $28.42 \mathrm{c}$ & 1.67 & 2.00 & $1.83 \mathrm{dc}$ \\
\hline B.j.+No.+30kgN & 73.58 & 68.78 & $71.18 \mathrm{~d}$ & 29.61 & 30.51 & $28.64 \mathrm{c}$ & 2.33 & 2.67 & $2.50 \mathrm{ab}$ \\
\hline B.j.+Ana.+30kgN & 78.40 & 78.63 & $78.51 \mathrm{ab}$ & 27.99 & 29.29 & $30.06 \mathrm{~b}$ & 1.67 & 2.33 & $2.00 \mathrm{bc}$ \\
\hline B.j.+No.+Ana.+30kgN & 80.48 & 80.88 & $8.62 \mathrm{a}$ & 31.52 & 33.49 & $32.50 \mathrm{a}$ & 2.67 & 2.67 & $2.67 \mathrm{a}$ \\
\hline L.S.D. at 0.05 & 2.71 & & 1.24 & & 0.57 & & \\
\hline
\end{tabular}

S1: First season, S2: Second season 


\section{Effect of microbial inoculation on nodulation status of soybean plant root.}

Data presented in Table (2) indicated that, all the tested treatments stimulated the nodulation status of plant roots. Cyanobacteria singlely or combined with rhizobia caused significant increases in number and dry weight of nodules, as well as nitrogenase activity. Mixed inoculation of all strains achieved the highest increase that reached $311 \%, 251 \%$ and $115.37 \%$ above the control, for number and dry weight of nodules and nitrogenase activity, respectively. These results are in accordance with the findings of Dashti et al ., (1998) who found that, co-inoculation of soy bean with $B$. japonicum and PGPR increased nodules number and hastened the $\mathrm{N}_{2}$ fixation. Also, Thilak et al., (2006) showed that coinoculation with RhizobiumAzospirillum or any PGPR could affect the growth and nitrogen fixation by increasing the infection sites that were later occupied by rhizobia and enhancing the occupancy of introduced Rhizobium in nodules of legume. Similar finding, confirming that the co- inoculation increased nodulation of legume roots, was observed by El-Howeity (2004) and Abdel-Wahab et al. (2006) whom reported that co-inoculation of some legumes with rhizobacteria exerted beneficial effects on nodulation of faba bean and peanut plant roots.

Co-inoculation of common bean $(P$. vulgaris L.) with Rhizobium tropici-CIAT 899, P. polymyxa-DSM36 and P. polymyxa-Loutit strains resulted in greater growth compared to inoculation with Rhizobium alone. Furthermore, co-inoculation exhibited greater nodulation (number and biomass) and nitrogen content compared to droughtstressed plants inoculated with only Rhizobium (Figueiredo et al., 2008). Moreover, El-Howeity et al.(2009) and Zhang et al. (2016) reported that, coinoculation with Rhizobium and PGPR resulted in significant increases in number and dry weight of root nodules, and nitrogenase activity, as compared with control of faba bean and peanut plants under field conditions.

Table (2): Effect of cyanobacteria and rhizobial inoculation on nodulation status of (Glycin Mix.L) plants under field conditions

\begin{tabular}{|c|c|c|c|c|c|c|c|c|c|}
\hline \multirow{2}{*}{ Treatments } & \multicolumn{3}{|c|}{$\begin{array}{l}\text { Number of nodules/ } \\
\text { plant }\end{array}$} & \multicolumn{3}{|c|}{$\begin{array}{c}\text { Dry weight of } \\
\text { noules(g/plant) }\end{array}$} & \multicolumn{3}{|c|}{$\begin{array}{l}\text { Nitrogenase activity } \\
\text { (ARA) (n moles } \\
\text { ethylene/g soil/h) }\end{array}$} \\
\hline & S1 & S2 & Mean & S1 & S2 & Mean & S1 & S2 & Mean \\
\hline Control (60kgN) & 26 & 27 & $26.50 \mathrm{f}$ & 0.55 & 0.58 & $0.56 \mathrm{~g}$ & 24.70 & 21.89 & $23.29 \mathrm{f}$ \\
\hline Nostoc $+30 \mathrm{kgN}$ & 54.67 & 57.33 & $56.00 \mathrm{e}$ & 0.69 & 0.77 & $0.73 c$ & 33.44 & 27.56 & $30.50 \mathrm{e}$ \\
\hline Anabena+30kgN & 59.00 & 64.00 & $61.50 \mathrm{~d}$ & 0.78 & 0.86 & $0.82 \mathrm{e}$ & 41.48 & 33.01 & $37.24 \mathrm{~d}$ \\
\hline B. japonicum $+30 \mathrm{kgN}$ & 68.67 & 69.00 & $68.83 \mathrm{c}$ & 1.13 & 1.22 & $1.17 \mathrm{~d}$ & 46.69 & 38.70 & $42.69 \mathrm{~b}$ \\
\hline B.j.+No. $+30 \mathrm{kgN}$ & 80.33 & 84.67 & $82.5 \mathrm{~b}$ & 1.36 & 1.45 & $1.40 \mathrm{c}$ & 47.20 & 47.06 & $47.13 b$ \\
\hline B.j.+Ana.+30kgN & 83.33 & 83.67 & $83.50 \mathrm{~b}$ & 1.70 & 1.83 & $1.76 \mathrm{~b}$ & 47.10 & 44.63 & $45.86 \mathrm{~b}$ \\
\hline B.j.+No.+Ana.+30kgN & 108.67 & 109.67 & $109.16 \mathrm{a}$ & 1.91 & 2.04 & $1.97 \mathrm{a}$ & 50.75 & 49.58 & $50.16 \mathrm{a}$ \\
\hline S.D. at 0.05 & \multicolumn{3}{|l|}{5.17} & \multicolumn{3}{|l|}{0.065} & \multicolumn{3}{|l|}{2.08} \\
\hline
\end{tabular}

S1: First season, S2: Second season 


\section{Effect of microbial inoculation on yield and some of its attributes of soybean crop:}

Data presented in Table (3) showed that single inoculation by cyanobacteria or rhizobia and their coinoculation improved the number of soybean pods /plant, dry weight of pods/ plant and not clear with 100 seed weight. Mixed inoculation of rhizobia + Nostoc + Anabaena scored the highest value of number of pods/plant when gave an increase $17.63 \%$ above the control. Also, the increase of dry weight of pod reached $26.73 \%$. Increases in the number of pods, dry weight of pods and 100 seeds weight were certainly referred to the microbial coinoculation which improved soil structure and porosity via secretion of polysaccharides and mucilage (Nain et al., 2010).

\section{Effect of microbial inoculation on some biochemical constituents of soybean seeds:}

Contents of oil, protein and carbohydrate in the seeds of soybean, subjected to different microbial inoculants, i.e. Nostoc, Anabaena, Rhizobium, either singly or in combination are presented in Table (4). The highest oil content was recorded by using the combined inoculation of the used $\mathrm{N} 2$ fixers, revealing the order: B.j.+Nostoc $>$ B.j. +Anabaena > B.j. + Anabaena ,respectively. Protein content was also improved with the mixed inoculation, wheres, rhizobial inoculation was more effective than the single cyanobacterial strains, but coinoculation with all strains significantly increased protein percent to $3.06 \%$ approximately. Likewise, coinoculation resulted in a similar action on carbohydrate contents in soy bean seeds, as compared with the other treatments.

Table (3): Effect of cyanobacteria and rhizobial inoculation on yield of soybean plants under field conditions

\begin{tabular}{|l|c|c|c|c|c|c|c|c|c|}
\hline \multirow{2}{*}{ Treatments } & \multicolumn{3}{|c|}{$\begin{array}{c}\text { Number of pods/ } \\
\text { plant }\end{array}$} & \multicolumn{3}{c|}{$\begin{array}{c}\text { Dry weight of pod } \\
\text { (g/plant) }\end{array}$} & \multicolumn{3}{c|}{100 seed weight (g) } \\
\cline { 2 - 11 } & $\mathrm{S} 1$ & $\mathrm{~S} 2$ & Mean & $\mathrm{S} 1$ & $\mathrm{~S} 2$ & Mean & $\mathrm{S} 1$ & $\mathrm{~s} 2$ & Mean \\
\hline Control $(60 \mathrm{kgN})$ & 64.67 & 67.67 & $66.16 \mathrm{c}$ & 20.77 & 21.07 & $20.91 \mathrm{~d}$ & 15.56 & 15.53 & $15.54 \mathrm{ab}$ \\
\hline Nostoc+30kgN & 54.00 & 58.33 & $56.16 \mathrm{~d}$ & 19.05 & 19.79 & $19.42 \mathrm{e}$ & 15.19 & 15.27 & $15.23 \mathrm{de}$ \\
\hline Anabena+30kgN & 53.00 & 56.33 & $54.66 \mathrm{~d}$ & 17.29 & 18.28 & $19.42 \mathrm{f}$ & 15.30 & 15.33 & $15.31 \mathrm{~cd}$ \\
\hline B. japonicum $+30 \mathrm{kgN}$ & 62.33 & 66.67 & $64.50 \mathrm{c}$ & 20.20 & 21.98 & $21.08 \mathrm{~d}$ & 15.24 & 15.65 & $15.44 \mathrm{bc}$ \\
\hline B.j.+No.+30kgN & 69.00 & 71.33 & $70.16 \mathrm{~b}$ & 23.25 & 24.60 & $23.92 \mathrm{~b}$ & 15.34 & 15.30 & $15.32 \mathrm{~cd}$ \\
\hline B.j.+Ana.+30kgN & 68.33 & 70.33 & $69.33 \mathrm{~b}$ & 21.57 & 24.16 & $22.86 \mathrm{c}$ & 15.01 & 15.19 & $15.10 \mathrm{e}$ \\
\hline B.j.+No.+Ana.+30kgN & 77.00 & 78.67 & $77.83 \mathrm{a}$ & 25.65 & 27.35 & $26.50 \mathrm{a}$ & 15.80 & 15.52 & $15.66 \mathrm{a}$ \\
\hline L.S.D. at 0.05 & 2.01 & & & 0.74 & & 0.19 & & \\
\hline
\end{tabular}

S1: First season, S2: Second season 
Table (4): Effect of cyanobacteria and Brady rhizobial inoculation on biochemical constituents of soybean seeds:

\begin{tabular}{|l|c|c|c|c|c|c|c|c|c|}
\hline \multirow{2}{*}{ Treatments } & \multicolumn{3}{|c|}{ Oil \% } & \multicolumn{3}{c|}{ Protein \% } & \multicolumn{3}{c|}{ Carbohydrate \% } \\
\cline { 2 - 10 } & $\mathrm{S} 1$ & $\mathrm{~S} 2$ & Mean & S1 & S2 & Mean & S1 & S2 & Mean \\
\hline Control (60kgN) & 19.73 & 20.93 & $20.33 \mathrm{~b}$ & 39.62 & 40.01 & $39.81 \mathrm{bc}$ & 33.20 & 33.07 & $33.13 \mathrm{abc}$ \\
\hline Nostoc+30kgN & 20.23 & 21.05 & $20.63 \mathrm{~b}$ & 40.22 & 40.71 & $40.46 \mathrm{ab}$ & 32.64 & 33.18 & $32.91 \mathrm{bc}$ \\
\hline Anabena+30kgN & 19.80 & 20.22 & $20.01 \mathrm{~b}$ & 39.01 & 40.15 & $39.64 \mathrm{c}$ & 32.40 & 32.72 & $32.56 \mathrm{c}$ \\
\hline B. japonicum +30kgN & 22.16 & 23.11 & $22.63 \mathrm{a}$ & 40.56 & 41.46 & $41.01 \mathrm{a}$ & 33.88 & 33.06 & $33.46 \mathrm{ab}$ \\
\hline B.j.+No.+30kgN & 22.06 & 23.74 & $22.89 \mathrm{a}$ & 40.02 & 40.84 & $40.43 \mathrm{ab}$ & 34.38 & 32.93 & $33.65 \mathrm{a}$ \\
\hline B.j.+Ana.+30kgN & 22.40 & 22.77 & $22.58 \mathrm{a}$ & 39.22 & 40.06 & $39.64 \mathrm{bc}$ & 34.14 & 33.11 & $33.62 \mathrm{a}$ \\
\hline B.j.+No.+Ana.+30kgN & 22.52 & 23.18 & $22.84 \mathrm{a}$ & 40.33 & 41.33 & $41.03 \mathrm{a}$ & 33.70 & 33.30 & $33.49 \mathrm{ab}$ \\
\hline L.S.D. at 0.05 & \multicolumn{3}{|c|}{1.07} & & 0.83 & & 0.65 \\
\hline
\end{tabular}

S1: First season, S2: Second season

\section{Effect of microbial inoculation on yield and some of its attributes of soybean crop:}

Data resulted in Table (5) declare the effect of using single and /or mixed inoculation with rhizobia and cyanobacteria plus half dose of recommended nitrogen fertilizer, in a comparison with full dose of the mineral nutrient, on the seed and straw of soybean yields. The obtained results showed that, the single inoculation by cyanobacteria improved seed yield of the crop, but not significantly with the control. Microbial combination significantly increased seed yield compared with the control or the single inoculation. The full dose of nitrogen fertilizer scored the highest straw yield referring to the other treatments.

It is worthy to note that, using cyanobacteria or rhizobia as a single inoculant gave lower straw yield. The full dose of nitrogen fertilizer ( $60 \mathrm{~kg} \mathrm{~N}$ ) scored the highest straw yield, but not significant with the mixed inocula of all strains. Similar finding, confirming that the coinoculation increased yield of legume, was observed by El-Howeity et al. (2009), Sanchez et al.
(2014) and Zimmer et al. (2016) who reported that, coinoculation with rhizobia and PGPR increased yield and protein content of Phaseolus vulgares and soybean.

\section{Effect of microbial inoculation on microbial activity in rhizosphere soil of soybean plants:}

Microbial activity in the rhizosphere soil of soybean was evaluated by dehydrogenase activity (DHA) and presented in Fig. (1). Results exerted that, the application of microbial inoculation significantly increased DHA. Coinoculation treatments gained higher values of DHA. These increases of dehydrogenase activity might be due to the support of cyanobacteria, either singly or mixed with rhizobia. Such contribution encouraged all endogenous microorganisms in the soil and also stimulated the root growth of the soybean plants, since cyanobacteria represented a source of organic matter which favours the activity of the majority of soil microorganisms. Dehydrogenase activity depends on the metabolic state of soil microorganisms (Frankenberger and Dick 
1983). Nain et al., (2010) found that, inoculation of wheat with cyanobacteria increased dehydrogenase activity under field conditions.
Finally, the present results confirm the benefits of the combined microbial inoculation, including cyanobacteria together with the specific rhizobia, for legume cultivation, particularly soybean.

Table (5): Effect of cyanobacteria and rhizobial inoculation on seed and straw yields of soybean plants

\begin{tabular}{|l|c|c|c|c|c|c|}
\hline \multirow{2}{*}{ Treatments } & \multicolumn{3}{|c|}{ Seed yield (ton/fed.) } & \multicolumn{3}{c|}{ Straw yield (ton/fed.) } \\
\cline { 2 - 7 } & $\mathrm{S} 1$ & $\mathrm{~S} 2$ & Mean & $\mathrm{S} 1$ & $\mathrm{~S} 2$ & Mean \\
\hline Control $(60 \mathrm{kgN})$ & 1.55 & 1.62 & $1.58 \mathrm{~cd}$ & 3.64 & 3.65 & $3.64 \mathrm{a}$ \\
\hline Nostoc+30kgN & 1.54 & 1.51 & $1.52 \mathrm{~d}$ & 3.59 & 3.62 & $3.60 \mathrm{ab}$ \\
\hline Anabaena+30kgN & 1.51 & 1.56 & $1.53 \mathrm{~d}$ & 3.47 & 3.57 & $3.52 \mathrm{c}$ \\
\hline B. japonicum +30kgN & 1.62 & 1.65 & $1.63 \mathrm{c}$ & 3.55 & 3.59 & $3.57 \mathrm{abc}$ \\
\hline B.j.+No.+30kgN & 1.69 & 1.75 & $1.72 \mathrm{~b}$ & 3.57 & 3.55 & $3.55 \mathrm{bc}$ \\
\hline B.j.+Ana.+30kgN & 1.74 & 1.77 & $1.75 \mathrm{~b}$ & 3.50 & 3.55 & $3.52 \mathrm{c}$ \\
\hline B.j.+No.+Ana.+30kgN & 1.82 & 1.90 & $1.86 \mathrm{a}$ & 3.62 & 3.64 & $3.63 \mathrm{a}$ \\
\hline L.S.D. at 0.05 & & 0.06 & & 0.07 & \\
\hline
\end{tabular}

S1: First season, S2: Second season

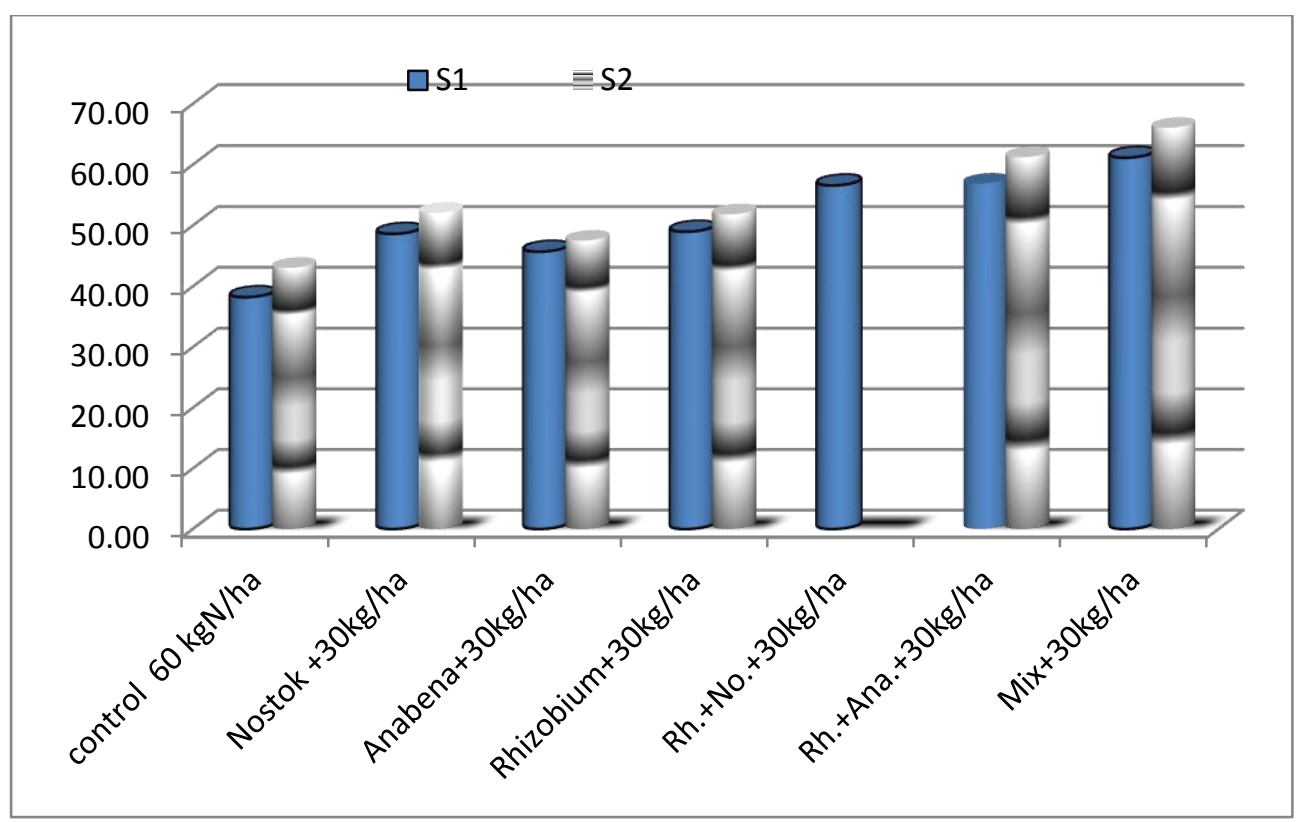

Fig. (1): Effect of cyanobacteria and B. japonicum inoculation on dehydrogenase activity "DHA" in rhizosphere soil of soybean plants. 


\section{REFERENCES}

Abdel-wahab, A.F., G.A.A. Mekhemar, Heba Shehata and Awaref A. Hanafi (2006) Effect of plant growth bioprotecting and promoting rhizobacteria and compost on the healthy and productivity of peanut crop in sandy soil. Minufiya J.Agric.Res., 31 (5):1323-1348.

A.O.A.C. (1990). Official Methods of Analysis of the Association of Official Analysis Chemists, (K. Helrich, ed) A.O.A.C.Inc., 15 th Edition, Virginia, USA.

Aref, M. Elham and A.R. Al-Kassas (2006). Cyanobacteria inoculation as nitrogen source may substitute partially mineral nitrogen in maize production . J. Agric. Sci. Mansoura Univ., 31(8): 5367-5378.

Badawy, A.M., T.M. El-Katony, M.S. Serg and M.A. Mousa (1996). Potentiality of Azolla filiculoides Lam. For nitrogen fixation and its use as biofertilizer for rice. Egypt j.Bot., 36: 109- 128.

Bergman, B., A.N. Rai and U. Rasmussen (2007). Cyanobacterial associations. In: Elmerich C, Newton WE (eds) Associative and endophytic nitrogen fixing bacteria and Cyanobacterial associations. Springer, Dordrecht :257301.

Dashti, N., F. Zhang, R. Hynes and D.L. Smith(1998). Plant growth promoting rhizobacteria accelerate nodulation and increasenitrogen fixation activity by field grown soybean (Glycine max L.) under short season conditions. Plant and Soil , 200:205-213.

Dubois, M., K.A. Gilles, J.K. Hamilton, P.A. Robers and F. Smith (1956). Colorimetric method for determination for sugar and related substances. Analytical chem., 28(3): 350-356.

El-Agroudy, N., S. Mokhtar, E. Awad-Zaghol and M.El-Gebaly (2011).An economic study of the production of soybean in Egypt. Agric Biol J N Am.; 2(2):221-225.

El-Howeity, M.A. (2004). Colonization patterns of diazotrophs associated with legume and non-legune crops. Ph.D.,
Dep. Soil Sci., Fac. Agric., Minufiya Univ., Egypt.

El-Howeity, M.A., A.A. Abdalla, Hanaa A. Abo-Kora and M.M. El-Shinnawi (2009). Response of faba bean plants to inoculation with Rhizobium leguminosarium and other Rhizobacteria under three nitrogen leves in newly reclaimed soil. J.Agric. Sci. Mansoura Univ. ,34(6): 7259-7272.

El-Sayed, S., M. El-Howeity, S. El-Hendawy and U. Sehmidhalter (2016). Noninvasive spectral detection of the beneficial effect of Bradyrhizobium and plant growth -promoting Rhizobacteria under different levels of nitrogen application on the biomass, nitrogen status, and yield of peanut cultivars. J. Bragantia, under puplacation.

Figueiredo, M.V.B., H.A., Burity, C.R., Martìnez and C.P. Chanway (2008). Alleviation of drought stress in the common bean (Phaseolus vulgaris L.) by co-inoculation with Paenibacillus polymyxa and Rhizobium tropici. Appl. Soil Ecol. 40: 182-188.

Frankenberger, Wt. and WA. Dick (1983). Relationship between enzyme activites and microbial growth and activity indices in soil. Soil Sci.Soc. Am J, 47:945-951.

Gomez, K.A. and A.A. Gomez (1984). Statistical Procedure for Agriculture Research. A Wiley Interscience Publication, John Wiley and Sons Inc. , New York, USA.

Hardy, R.W.F., R.C. Burus and R.D. Holsten (1973). Application of the acetylene ethylene assay for measurements of nitrogen fixation, Soil Biol. Biochem., 5:47-81.

Hungria, M. and M.A. Nogueira (2013). Coinculation of soybeans and common beans with rhizobia and Azospirilla: Strategies to improve sustainability .Biol.Fertil. Soils, 49: 791-801.

Karthikeyen, N., R. Prasanna, L. Nain and B.D. Kaushik (2007) . Evaluating the potentianl of plant growth promoting 
cyanobacteria as inoculants for wheat. Eur.J.Soil Biol., 43:23-30.

Kumar, P., P. Pandey, R.C. Dubey and D.K. Maheshwari (2016). Bacteria consortium optimization improves nutrient uptake, nodulation, disease suppression and growth of the common bean (Phaseolus vulgaris) in both pot and field studies. Rhizosphere,2: 13-23.

Masuda, T. and PD. oldsmith (2009). World Soybean Production: Area Harvested, Yield, and Long-Term Projections. International Food and Agribusiness Management Review,12(4):143-162.

Nain, L., A. Rana, M. Joshi, D. Shrikrishna, D. Kumar, Y.S. Shivay S. Paul and R. Prasanna (2010). Evaluation of synergistic effects of bacterial and cyanobacterial strains as biofertilizers for wheat. Plant Soil , 331:217-230.

Page, A.L., R.H. Miller and D.R. Keeney (1982). Methods of Soil Analysis. Part 2, 2 nd ed. Amer.Soc.Agron. , Inc., Mad., Wisc., USA.

Prasanna, R., A. Pabby, S. Saxena and PK. Singh (2004). Modulation of pigment profiles of Calothrix elenkenii in response to environmental change. J Plant Physiol, 161:1125-1132.

Sánchez, A. C., R. T. Gutiérrez, R. C. Santana, A. R. Urrutia, M. Fauvart, J. Michiels and J. Vanderleyden (2014). Effects of co-inoculation of native Rhizobium and Pseudomonas strains on growth parameters and yield of two contrasting Phaseolus vulgaris $\mathrm{L}$. genotypes under Cuban soil conditions. Europ. J. of Soil Biol., 62:105-112.

Sekina, T.A. Tantawy and Nagwa M. Atef (2010). Growth responses of Lupinus termis to some plant growth promoting cyanobacteria and bacteria as biofertilizers. J.of Food, Agric.\& Environ., 8(3\&4): 1178-1183.

Sergeeva, E., A. Liaimer and B. Bergman (2002). Evidence for production of the phytohormone indole -3-acetic acid by cyanobacteria. Planta, 215: 229- 238.

Thalmann, A. (1967). Uber die microbiello aktiviatat merkmalen einiger acherboden unter besonderer beruksi chtigung der dehydrognase activiatat (T.T.C. Reduktion). Biss, Gieben. Ph.D. Thesis, W. Germany.

Thilak, K. V. B. R., N. Ranganayaki and C. Manoharachari (2006). Synergistic effects of plant-growth promoting rhizobacteria and Rhizobium on nodulation and nitrogen fixation by pigeonpea (Cajanus cajan). European Journal of Soil Science, 57: 67-71.

Trabelsi, D., H.B. Ammar, A. Mengoni and R. Mhamdi (2012). Appraisal of the croprotation effect of rhizobial inoculation on potato cropping systems in relation to soil bacterial communities.Soil Biol.Biochem, 54: 1-6.

Zhang, W., W. Wang, X. Wang, X. Xie, M. Siddikee, R. Xu and C. Dai (2016). Enhanced nodulation of peanut when coinoculation with fungal endophyte Phomopsis liqudambari and Bradyrhzobium. Plant physiology and Bioch., 98: 1-11.

Zimmer, S., M. Messmer, T. Haasec, $H$. Piephoe, A. Mindermannd, H. Schulz, A. Habeku, F. Ordon and K. Wilbois J. Heß (2016). Effects of soybean variety and Bradyrhizobium strains on yield, protein content and biological nitrogen fixation under cool growing conditions in Germany. Europ. J. Agronomy, 72: 3846. 


\section{استجابة نباتات فول الصويا للتثيح المشترك بين الريزوييا والسيانويكتيريا}

\section{محمد احمد الحويطى (1) ، شبل عبدالله عبد الجواد (2)}

$$
\begin{aligned}
& \text { (1) معهد الدراسات والبحوث البيئية - جامعة مدينة السادات } \\
& \text { (2) معهد بحوث الاراضى والمياه والبيئة - مركز البحوث الزراعية } \\
& \text { الملخص العربى }
\end{aligned}
$$

تم زراعة تجربة حقلية لموسميين منتالين لنبات فول الصويا عامى 2013/2012- 2014/2013 ، فى ارض

$$
\begin{aligned}
& \text { رسوبية طينية وذللك لتقييم اثر المعاملات الاتية : } \\
& \text { 1- كنترول (60 وحدة ازوت) للفدان }
\end{aligned}
$$

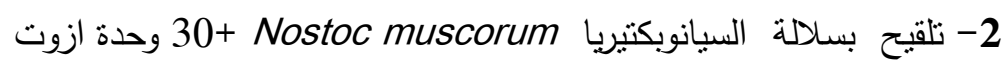

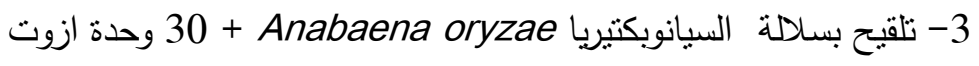

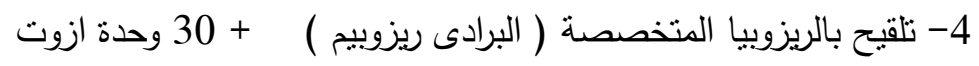

5- تلقيح مشترك بين كل من : البرادى ريزوبيم والسيانوبكتبريا ( Nostoc muscorum + 30 وحدة ازوبيا )

6- تلقيح مشترك بين كل من : السيانوبكثبريا و البرادى ريزوبيوم ( Anabaena oryzae + 30 وحدة ازوت) 7- تلقيح مشترك بين كل السلالات : البرادى ريزوبيم والسيانوبكتيريا (Anabaena + Nostoc muscorum)

$$
\text { ( } 30 \text { + oryzae }
$$

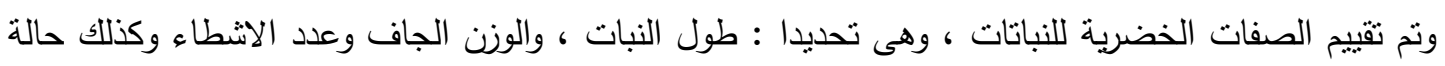

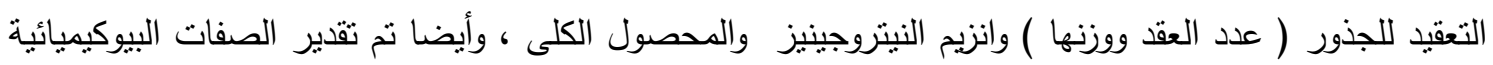
للبذور مثل( نسبة الزيت - البروتين مو الكربوهيدرات)، كذلك النشاط الحيوى فى ريزوسفير النباتات (بتقدير انزيم الديهيدروجينيز) (لإن) وأظهرت النتائج زيادة معنوية للصفات الخضرية مع التسميد الحيوى لكل المعاملات الميكروبية مقارنة بباقى الاضافات والكنترول ـ وقد تفوق التسميد المشترك معنويا مقارنة بالتسميد المنفرد ـ وحقق استخدام السيانوبكتيريا

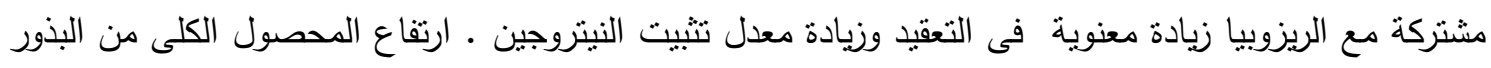

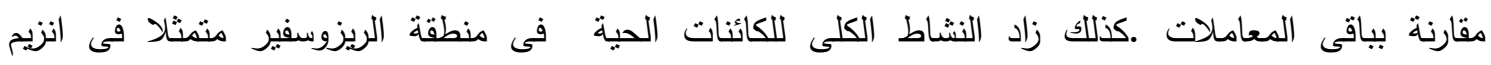

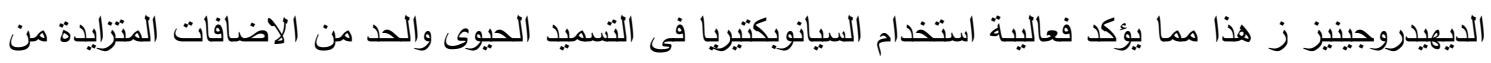
التسميد الكيماوى والحفاظ على البيئة . 